One mild hypersensitivity reaction was observed in this series of 10 patients, in contrast to a $41 \%$ incidence of reactions in cystinurics treated with D-penicillamine in four other reported series. None of the other side-effects reported elsewhere for D-penicillamine was observed in this study.

Thanks are due to Dr. E. Alpert, Merck Sharp \& Dohme, West Point, Pa., U.S.A., for generous supplies of D-penicillamine and $N$-acetyl-D-penicillamine used in these studies.

\section{REFERENCES}

Aposhian, H. V. (1961). Fed. Proc., 20, Suppl. No. 10, p. 185

and Aposhian, M. M. (1959). F. Pharmacol. exp. Ther., 126, 131. Asatoor, A. M. (1964). Nature (Lond.), 203, 1382.

Barter, F. C., Lotz, M., Thier, S., Rosenberg, L. E., and Potts, J. T., jun. (1965). Ann. intern. Med., 62, 796.

Boulding, J. E., and Baker, R. A. (1957). Lancet, 2, 985.

Coxon, V., and Kolb, F. O. (1954). Metabolism, 3, 255

Crawhall, J. C., Scowen, E. F., and Watts, R. W. E. (1963). Brit. med. †., 1,588 .

(i964). Ibid., 1, 1411.

Dent, C. E., Friedman, M., Green, H., and Watson, L. C. A. (1965). Ibid., 1, 403.

du Vigneaud, V., Kuchinskas, E. J., and Horvath, A. (1957). Arch. Biochem., 69, 130. Eldjarn, L., and Hambraeus, L. (1964). Scand. F. clin. Lab. Invest., 16,

Fellers, F. X., and Shahidi, N. T. (1959). Amer. F. Dis. Child., 98, 669.
Goldberg, A., Smith, J. A., and Lochhead, A. C. (1963). Brit. med. J., 1, 1270.

Gubler, C. J., Lahey, M. E., Ashenbrucker, H., Cartwright, G. E., and Wimtrobe, M. M. (1952). F. biol. Chem., 196, 209.

Harris, E. D. jun and Sjoerdsma, A (1966). Lancet, 2, 996.

Henry, R. J., Sobel, Ch., and Chiamori, N. (1958). Clin. chim. Acta, 3, S23.

Jaffe, I. A., Altman, K., and Merryman, P. (1964). \}. clin. Invest., 43, 1869.

Lewis, H. B. (1932). Ann. intern. Med., 6, 183.

Lotz, M., and Bartter, F. C. (1965). Brit. med. ๆ., 2, 1408.

- Potts, J. T., jun., and Bartter, F. C. (1965a). Milit. Med., 130, 768.

(1965b). Brit. med. 7., 2, 521

Holland. J. M., Kiser, W. S., and Bartter, F. C. (1966). 3. Urol., 95, 257.

McDonald, J. E., and Henneman, P. H. (1965). New Engl. Ұ. Med., 273, 578 .

MacDonald, W. B., and Fellers, F. X. (1966). F. Amer. med. Ass., 197. 396.

Nimni, M. E., and Bavetta, L. A. (1965). Science, 150, 905.

Patch, F. S. (1934). Canad. med. Ass. F., 31, 250.

Scheinberg, I. H. (1964). 7. chron. Dis., 17, 293.

Smith, D. R., Kolb, F. O., and Harper, H. A. (1959). F. Urol., 81, 61.

Sternlieb, I., and Scheinberg, I. H. (1964). F. Amer. med. Ass., 189, 748.

Stokes, G. S., Potts, J. T., jun., Lotz, M., and Bartter, F. C. (1966a). Clin. Res., 14, 390. (1966b). Abstracts of 3rd International Congress on Nephrology, p. 280.

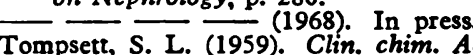

Tompsett, S. L. (1959). Clin. chim. Acta, 4, 411.

Walshe, J. M., and Clarke, V. (1965). Arch. Dis. Childh., 40, 651

Williams, R. J. P. (1961). Fed. Proc., 20, Suppl. No. 10, p. 190.

Zinneman, H. H., and Jones. J. E. (1966). Metabolism, 15, 915.

\title{
Comparison of Symptoms after Vagotomy with Gastrojejunostomy and Partial Gastrectomy
}

\author{
ALAN G. COX, * M.D., F.R.C.S.ED.
}

Brit. med. F., i $968,1,288-290$

The choice of operation for chronic duodenal ulcer has been debated vigorously but opinion remains divided. Properly controlled prospective clinical trials are needed to provide a true comparison between the effects of different operations. Such a trial to evaluate the results of the Polya partial gastrectomy with vagotomy and gastrojejunostomy has been conducted at the Western Infirmary, Glasgow, since 1954. This paper reports a comparison of symptoms in patients who were treated at least eight years ago.

\section{Method of Study}

Male patients coming to elective surgery for chronic duodenal ulcer were treated either by total vagotomy with gastrojejunostomy or by the Polya partial gastrectomy. The choice of operation was determined by random selection after exploration of the abdomen had confirmed the diagnosis and shown that either operation could be performed with safety.

All patients operated on at least eight years previously were included. Of 106 patients available for study 55 had had a partial gastrectomy and 51 vagotomy with gastrojejunostomy (Table I). The two groups of patients showed striking similarities when age, height, weight, and time since operation were compared (Table II).

Each patient underwent an interview which lasted 30 to 40 minutes. In order to ensure standard conditions each interview comprised a series of identical questions asked in the same order and with a minimum of prompting and discussion. Most

- Department of Surgery, Western Infirmary, Glasgow. Present address : Department of Surgery, Royal Postgraduate Medical School, Ducane Road, London W.12. questions related to alimentary symptoms, and, if present, their severity was noted as mild, moderate, or severe. The patients were then asked to give their own opinion of the symptomatic outcome of the operation by choosing one of four descriptions : no alimentary symptoms, mild symptoms, moderate symptoms, severe symptoms. Finally, they were placed in one of the following clinical grades: grade 1, no alimentary symptoms; grade 2, mild, easily controlled symptoms; grade 3 , poorly controlled symptoms which did not interfere significantly with enjoyment of life or capacity for work; grade 4, symptoms which did interfere with enjoyment of life or capacity for work ; or grade 5 , recurrent ulcer or severe symptoms.

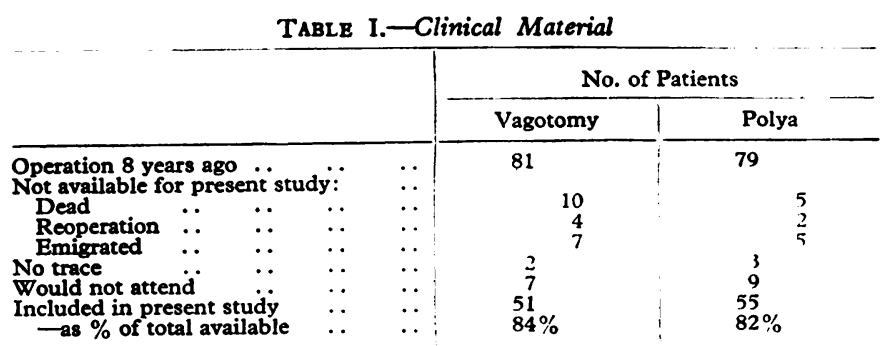

TABLB II.-Similarity of Patients After the Two Different Operations

\begin{tabular}{|c|c|c|c|c|}
\hline & & & \multicolumn{2}{|c|}{ Mean \pm S.D. } \\
\hline & & & Vagotomy & Polya \\
\hline $\begin{array}{l}\text { Age in years } \\
\text { Height in cm. } \\
\text { Weight in kg. } \\
\text { Months since operation }\end{array}$ & $\begin{array}{l}\because \\
\because \\
\cdots\end{array}$ & \begin{tabular}{l|}
$\because$. \\
$\therefore$
\end{tabular} & $\begin{array}{c}48 \cdot 3 \pm 8 \cdot 4 \\
170 \cdot 1 \pm 6 \cdot 9 \\
62 \cdot 9 \pm 7 \cdot 2 \\
102 \cdot 4 \pm 17 \cdot 1\end{array}$ & $\begin{array}{c}49 \cdot 8 \pm 8 \cdot 7 \\
169 \cdot 0 \pm 6 \cdot 5 \\
61 \cdot 1 \pm 7 \cdot 6 \\
104 \cdot 7 \pm 12 \cdot 3\end{array}$ \\
\hline
\end{tabular}


Analysis of the findings was carried out to compare the symptomatic results of the two operations. The large number of qualitative data required condensation to achieve a comprehensible assessment. Therefore the number of grades was reduced in appropriate parts of the analysis in order to provide a direct comparison of the incidence of clinically significant problems. In particular a symptom score was derived for each patient. For this purpose each symptom was scored as follows : absent, 0 ; mild, 1 ; moderate, 2 ; severe, 3.

The symptom score for each patient was calculated by adding together the scores for each of his symptoms. Since 27 symptoms were recorded the maximum possible score was 81 $(27 \times 3)$ and the minimum was $0(27 \times 0)$ for an individual patient.

\section{Results}

Incidence of Alimentary Symptoms.-Symptoms graded as moderate or severe were regarded as clinically important and their combined incidence after each operation was compared (Table III). The incidence of most symptoms was low and there were few differences between the two groups of patients. A sensation of undue fullness after meals was more common after partial gastrectomy and the difference was significant $(P<0.01)$. This corresponded with an inability to eat large meals and a high incidence of postcibal vasomotor symptoms in patients who had had partial gastrectomy. Of the 27 symptoms listed in Table III, 15 were more common after partial gastrectomy, 7 after vagotomy, and 5 occurred equally in the two groups.

TABLE III.-Percentage Incidence of Moderate and Severe Symptoms

\begin{tabular}{|c|c|c|c|c|c|c|c|c|}
\hline & & $\begin{array}{l}\text { Vagot- } \\
\text { omy }\end{array}$ & Polya & & & & $\begin{array}{l}\text { Vagot- } \\
\text { omy }\end{array}$ & Polya \\
\hline 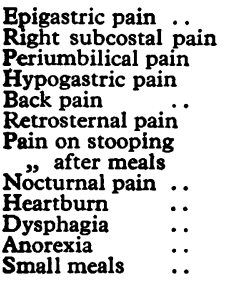 & 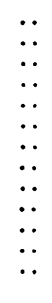 & $\begin{array}{r}6 \\
0 \\
4 \\
0 \\
0 \\
2 \\
0 \\
0 \\
2 \\
6 \\
6 \\
4 \\
10\end{array}$ & $\begin{array}{r}5 \\
0 \\
7 \\
0 \\
4 \\
0 \\
0 \\
4 \\
2 \\
4 \\
0 \\
7 \\
27\end{array}$ & $\begin{array}{l}\text { Nausea } \\
\text { "Acid" } \\
\text { Food vo } \\
\text { Bile von } \\
\text { Excess } \\
\text { Excess } \\
\text { Excess } \\
\text { Soon } \\
\text { after } \\
\text { meals } \\
\text { Hunger } \\
\text { Colic } \\
\text { Disturb }\end{array}$ & $\begin{array}{l}\text { vomiting } \\
\text { miting } \\
\text { iiting } \\
\text { pelching } \\
\text { orborygmi } \\
\text { latus ... } \\
\text { Fullness } \\
\text { Fatigue } \\
\text { Faintness } \\
\text { Sweating } \\
\text { attacks } \\
\text { ed bowels }\end{array}$ & 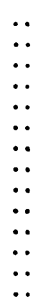 & $\begin{array}{r}8 \\
2 \\
4 \\
6 \\
8 \\
2 \\
6 \\
24 \\
25 \\
4 \\
6 \\
6 \\
2 \\
0\end{array}$ & $\begin{array}{r}9 \\
1 \\
4 \\
7 \\
5 \\
4 \\
11 \\
47 \\
33 \\
11 \\
13 \\
4 \\
4 \\
7\end{array}$ \\
\hline
\end{tabular}

Number of Symptoms per Patient.-The average number of symptoms was lower in the patients who had had vagotomy than in those who had had partial gastrectomy. This applied to mild, moderate, and severe symptoms, but the differences were not statistically significant (Table IV).

TABLB IV.-Average Number of Symptoms in Each Patient

\begin{tabular}{llll|c|c|c}
\hline \multicolumn{3}{c|}{ Grade of Symptom } & & Vagotomy & Polya \\
\hline Mild &. & $\ldots$ &. & $\ldots$ & $2 \cdot 8$ & 3.3 \\
Moderate & $\cdots$ & $\cdots$ & $\cdots$ & $\cdots$ & 1.6 & 1.9 \\
Severe &. & $\cdots$ & $\cdots$ & $\cdots$ & 0.1 & 1.4 \\
\hline
\end{tabular}

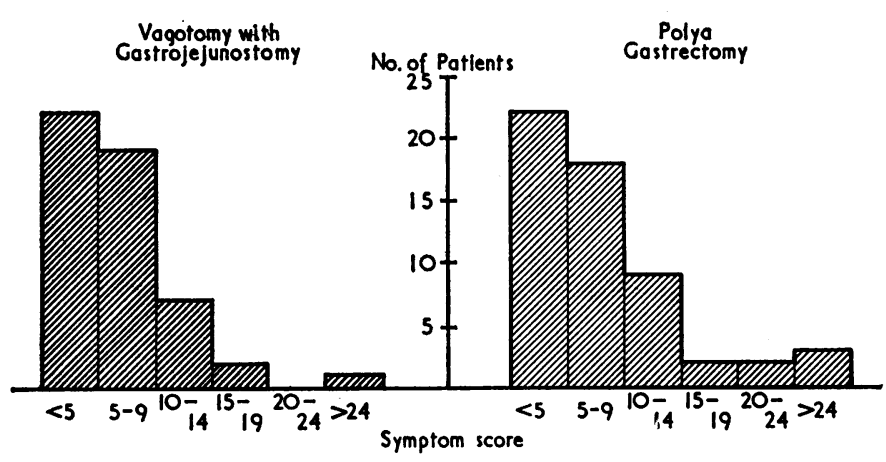

FIG. 1.-Frequency distribution of symptom scores (see text) after vagotomy with gastrojejunostomy and after the Polya partial gastrectomy.
Symptom Score.-The mean symptom score for patients after partial gastrectomy (8.2, S.D.6.9) was greater than that for patients after vagotomy (6.2, S.D.4.2), but this difference was not significant $(P=0.11)$. The distribution of symptom scores (Fig. 1) suggested that there was little difference between the two groups though the number of unduly high values was greater after gastrectomy than after vagotomy.

Overall Assessment.-The results of clinical grading and of asking the patients their own assessment of the symptomatic outcome of operation were recorded (Table V). As with the previous analysis the findings were slightly in favour of vagotomy, but the differences were not significant.

TABLE V.-General Evaluation of Symptomatic Outcome

\begin{tabular}{c|c|c|c|c|c}
\hline \multicolumn{2}{c|}{ Medical Evaluation } & \multicolumn{3}{c}{ Patient's Evaluation } \\
\cline { 1 - 2 } $\begin{array}{c}\text { Clinical } \\
\text { Grade }\end{array}$ & \multicolumn{2}{|c|}{ No. of Patients } & & Symptoms & \multicolumn{2}{c}{ No. of Patients } \\
\cline { 2 - 5 } & Vagotomy & Polya & & Vagotomy & Polya \\
\hline 1 & 20 & 16 & None & 30 & 25 \\
2 & 20 & 25 & Mild & 14 & 18 \\
3 & 6 & 8 & Moderate & 6 & 9 \\
4 & 4 & 5 & Severe & 1 & 3 \\
5 & 1 & 1 & & & \\
\hline Total & 51 & 55 & Total & 51 & 55 \\
\hline
\end{tabular}

Bowel Habit.-This was analysed in detail because of current interest in this subject, particularly in relation to vagotomy. The incidence of episodic diarrhoea was higher after vagotomy, but in those affected the frequency and severity of attacks seemed similar in the two groups of patients (Fig. 2, Table VI). Moderate and severe symptoms were more common after gastrectomy than after vagotomy (see Table III).

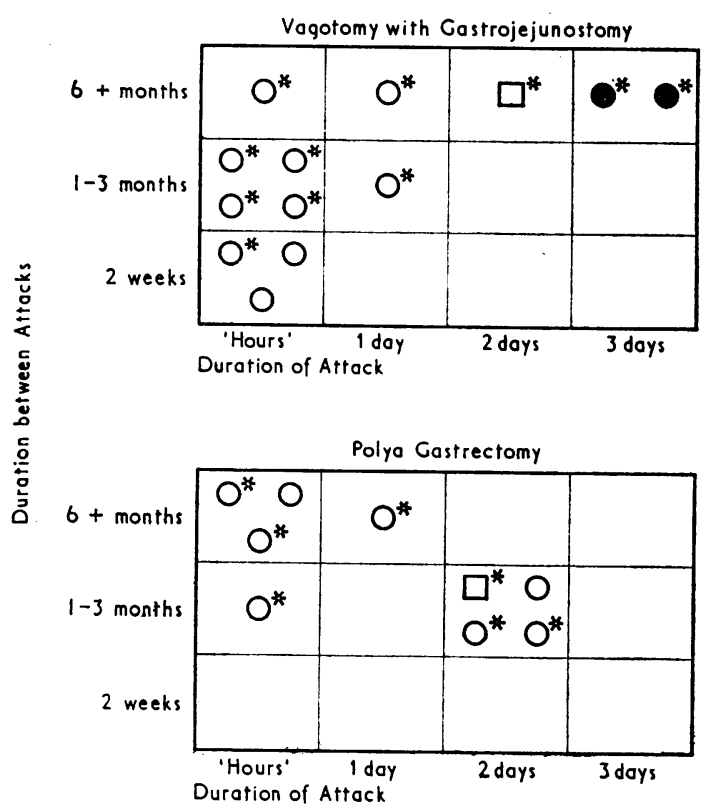

FIG. 2.-Frequency, duration, and severity of attacks of diarrhoea after vagotomy with gastrojejunostomy and after partial gastrectomy. The number of motions in each attack is represented as follows: $O=$ up to $5, \square=6$ to 10 , attack is represented as follows: $O=$ up to $5, \square=6$ to 10 ,
$=$ more than 10 . Attacks marked with an asterisk were $=$ more than 10 . Attacks marked with an asterisk were
associated with urgency. (One gastrectomy patient is omitted owing to lack of detail.)

TABLE VI.-Comparison of Features of Bowel Habit

\begin{tabular}{|c|c|c|c|c|c|}
\hline \multirow{2}{*}{\multicolumn{4}{|c|}{ Feature }} & \multicolumn{2}{|c|}{ No. of Patients } \\
\hline & & & & Vagotomy & Polya \\
\hline $\begin{array}{l}\text { No. of } \\
\text { motions } \\
\text { per day } \\
\text { Irregularity } \\
\text { Aperients } \\
\text { Urgency } \\
\text { Attacks of di }\end{array}$ & $\begin{array}{l} \begin{cases}1 & \\
1-2 & \\
2-3 & \\
3 & \end{cases} \\
\quad \because\end{array}$ & $\begin{array}{l}\because \\
\because \\
\because \\
\because\end{array}$ & $\begin{array}{l}\because \\
\because \\
\because \\
\because \\
\because\end{array}$ & $\begin{array}{r}10 \\
29 \\
11 \\
1 \\
3 \\
13 \\
8 \\
13\end{array}$ & $\begin{array}{r}5 \\
39 \\
11 \\
0 \\
6 \\
13 \\
8 \\
9\end{array}$ \\
\hline
\end{tabular}


Deaths and Recurrent Ulcers.-The numbers and causes of deaths were compared (Table VII). One early postoperative death occurred after each operation. The total number of subsequent deaths after vagotomy was higher than that after Polya gastrectomy, but most of the deaths were from causes which seemed unrelated to the type of operation. Recurrent ulcer, proved at reoperation, was seen twice after partial gastrectomy and once after vagotomy. Three further patients had been suspected of recurrent ulceration after vagotomy. They were subjected to reoperation at other hospitals, but the operative findings were not available.

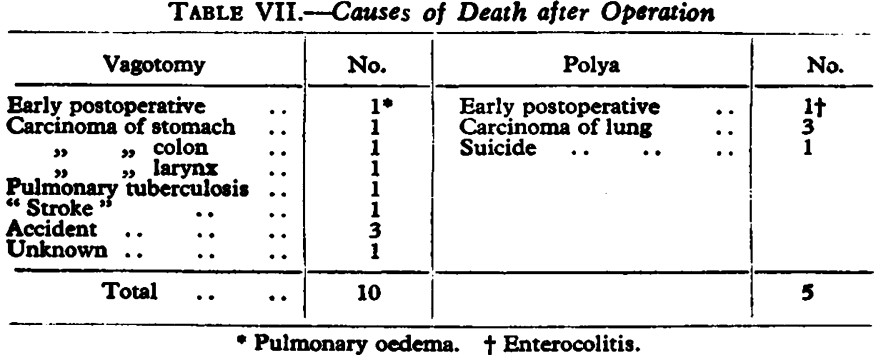

\section{Discussion}

Two main conclusions may be drawn from this study. The first is that any difference between the symptomatic results of the two operations is small. The second is that vagotomy with gastrojejunostomy gives slightly better symptomatic results. This suggests that vagotomy with gastrojejunostomy is marginally better than the Polya gastrectomy in terms of alimentary symptoms. A similar advantage for vagotomy was found in a detailed haematological study of the patients in the present study (Cox, Hutchison, and Wardrop, 1968).

The numbers of patients are small and definite conclusions are difficult to achieve. However, the differences are generally so slight that larger numbers would be unlikely to change the overall evaluation. Other factors must be taken into account in selecting the best operation. These include recurrent ulceration and deaths, both of which show a slight advantage for the Polya gastrectomy in the present investigation.
Many comparisons of different gastric operations have been published but few are based on properly designed prospective trials. One of the most distinguished contributions in this field is the clinical trial in Leeds, in which three operations are under study-vagotomy with gastrojejunostomy, vagotomy with antrectomy, and the Polya subtotal gastrectomy. Two years after operation there were relatively small differences (Goligher, Pulvertaft, and Watkinson, 1964), and the general pattern was much the same three to six years after operation (Goligher, Pulvertaft, and Franz, 1966). This accords with the findings of the present study. In both series the incidence of dumping symptoms is higher after gastrectomy and that of episodic diarrhoea is higher after vagotomy.

The current trend in the surgery of duodenal ulcer is toward operations which employ vagotomy as the principal feature because it decreases secretion of acid without reducing the capacity of the stomach. The main alternative, partial gastrectomy, seems likely to give a higher incidence of symptomatic discomforts. If this is accepted further trials are needed to compare the relative merits of different operations based upon vagotomy. Particular information is required on the choice of drainage procedure, the place of antrectomy, and the need for selective vagotomy.

\section{Summary}

A controlled trial of vagotomy with gastrojejunostomy and partial gastrectomy for chronic duodenal ulcer has been conducted since 1954. This paper reports and compares the symptomatic results in patients operated on at least eight years ago. In general, the differences are small but favour vagotomy. Fullness after meals was more common after gastrectomy and disturbed bowels more common after vagotomy.

It is a pleasure to thank all the surgeons who participated in this trial, in particular Sir Charles Illingworth, in whose department it was initiated, and Professor A. W. Kay, who gave invaluable advice and encouragement throughout the present study.

\section{REPBRENCES}

Cox, A. G., Hutchison, H. E., and Wardrop, C. J. (1968). Gut. In press. Goligher, J., Pulvertaft, C. N., and Franz, R. C. (1966). Conference on Postgraduate Gastroenterology, edited by T. J. Thomson and I. B. Gillespie, Chap. 26. London.

-1 and Watkinson, G. (1964). Brit. med. F., 1, 455.

\title{
Non-tuberculous Constrictive. Pericarditis
}

\author{
B. P. HARROLD,* M.B., B.S., M.R.C.P.
}

Brit. med. F., 1968, 1, 290-292

Constrictive pericarditis often occurs without a known cause. Out of 181 cases collected from the literature (Chambliss et al., 1951 ; Kaltman et al., 1953 ; Hansen and Hansen, 1959; Gimlette, 1959) only 46 were shown to be due to tuberculosis; in 103 no cause could be found.

Reports of the association between rheumatoid arthritis and pericardial constriction and between antecedent acute benign serous pericarditis and constriction are still only a few. The purpose of this report is to add to the literature two cases of pericardial constriction which occurred after rheumatoid arthritis and one after acute benign pericarditis.

\section{Case 1}

In October 1958 a previously healthy 53-year-old woman developed pain and swelling in her hands, knees, and feet. The E.S.R. was $29 \mathrm{~mm}$. per hour and the differential agglutination titre positive at a dilution of 1 in 128. No destructive changes were seen in her joints radiologically. Treatment with corticosteroids began in June 1959, aspirin, phenylbutazone, and hydroxychloroquine sulphate having previously failed. By August 1960 her differential agglutination titre had risen to 1 in 2,048 .

In January 1964 she had a spontaneous fracture of the left fibula, thought to have been due to prolonged corticosteroid treatment. In May she was found to have a lesser-curve gastric ulcer, and in September she had a haematemesis. In December a second minor haematemesis occurred. At this time the arthritis was active, with swollen, red, warm finger-joints, and there was a well-marked pericardial friction rub. She developed orthopnoea and sacral oedema, and radiography demonstrated cardiomegaly and pleural effusions. The electrocardiogram had low voltage and showed widespread T-wave flattening. The E.S.R. rose to a maximum of $86 \mathrm{~mm}$. per hour, and five L.E. preparations made on the serum

* Department of Medicine, University of Bristol. Present address: Freedom Fields Hospital, Plymouth. Devon. 